\title{
Implementasi Pelayanan Hak Tanggungan Terintegrasi Secara Elektronik di Kantor Pertanahan Kota Batam
}

\author{
Sarah Exaudia ${ }^{1}$, Wahyuni2 ${ }^{*}$, Akur Nurasa ${ }^{3}$ \\ ${ }^{1}$ Kantor Wilayah Badan Pertanahan Nasional Kepulauan Riau, JL. M.T. Haryono Bukit Bestari, Tanjungpinang \\ ${ }^{2}$ Sekolah Tinggi Pertanahan Nasional, Jl. Tata Bumi No. 5 Banyuraden, Yogyakarta \\ ${ }^{3}$ Sekolah Tinggi Pertanahan Nasional, Jl. Tata Bumi No. 5 Banyuraden, Yogyakarta \\ * Korespondensi: email: wahyuniwidigdo@stpn.ac.id
}

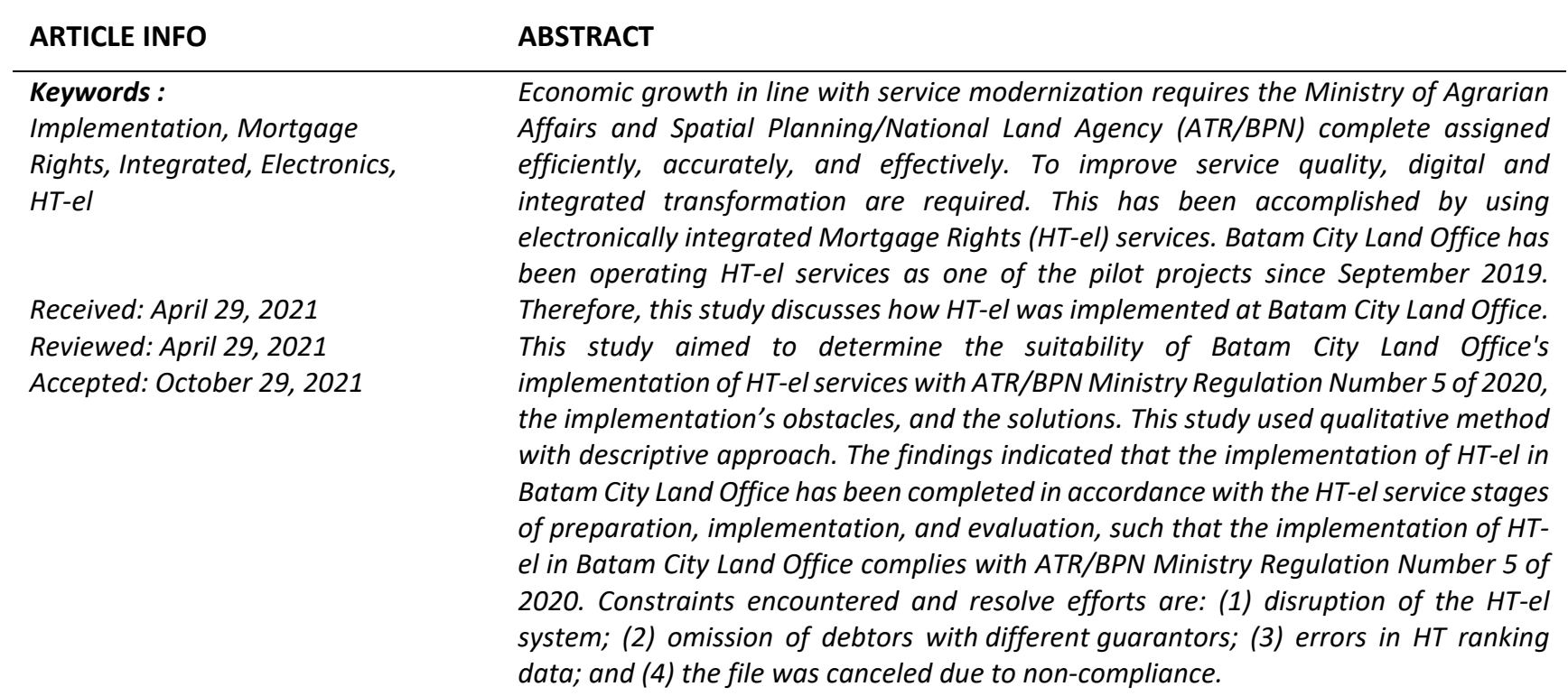

INFO ARTIKEL

\section{Kata Kunci:}

Implementasi, Hak Tanggungan, Terintegrasi, Elektronik, HT-el

\section{How To Cite :}

Sarah Exaudia, S., Wahyuni., Nurasa, A. (2021). Implementasi Pelayanan Hak Tanggungan Terintegrasi Secara Elektronik Di Kantor Pertanahan Kota Batam. Marcapada: Jurnal Kebijakan Pertanahan, 1(1), 42-60

\section{ABSTRAK}

Pertumbuhan ekonomi yang sejalan dengan modernisasi pelayanan menuntut Kementerian Agraria dan Tata Ruang/Badan Pertanahan Nasional (ATR/BPN) untuk menyelesaikan tugas yang diberikan secara efisien, akurat, dan efektif. Untuk meningkatkan kualitas layanan, diperlukan transformasi digital dan terintegrasi. Hal ini telah diwujudkan dengan menggunakan layanan Hak Tanggungan (HT-el) yang terintegrasi secara elektronik. Kantor Pertanahan Kota Batam telah mengoperasikan layanan HT-el sebagai salah satu pilot project sejak September 2019. Oleh karena itu, penelitian ini membahas bagaimana penerapan HT-el di Kantor Pertanahan Kota Batam. Tujuan dari penelitian ini adalah untuk mengetahui kesesuaian pelaksanaan pelayanan HT-el Kantor Pertanahan Kota Batam dengan Peraturan Menteri ATR/BPN Nomor 5 Tahun 2020, kendala pelaksanaan, dan solusinya. Penelitian ini menggunakan metode kualitatif dengan pendekatan deskriptif. Hasil penelitian menunjukkan bahwa pelaksanaan HT-el di Kantor Pertanahan Kota Batam telah selesai sesuai dengan tahapan pelayanan HT-el yaitu persiapan, pelaksanaan, dan evaluasi, sehingga pelaksanaan HT-el di Pertanahan Kota Batam Perkantoran sesuai Permen ATR/BPN Nomor 5 Tahun 2020. Kendala yang ditemui dan upaya penyelesaiannya antara lain: (1) gangguan sistem HT-el; (2) kelalaian debitur dengan penjamin yang berbeda; (3) kesalahan dalam data peringkat HT; dan (4) berkas dibatalkan karena tidak sesuai dengan persyaratan. 


\section{A. Pendahuluan}

Penanaman modal berupa investasi tanah merupakan satu cara rakyat untuk meningkatkan kesejahteraan ekonomi. Terbukanya akses rakyat kepada tanah dan melalui kuatnya hak rakyat atas tanah, maka kesempatan rakyat untuk memperbaiki sendiri kesejahteraan sosial ekonominya akan semakin besar serta martabat sosialnya akan meningkat (Wicaksono, 2015). Masyarakat yang memiliki hak atas tanah memiliki keistimewaan tersendiri, sebagai pemilik tanah dapat dilakukan perbuatan hukum atas tanah yang tersebut.

Di tengah pertumbuhan ekonomi, masyarakat setiap waktu selalu menuntut pelayanan publik yang berkualitas dari pemerintah. (Sinambela, 2011). Peningkatan pelayanan menjadi tantangan bagi administrasi pertanahan dalam menyelesaikan pekerjaan secara cepat, tepat dan efektif dengan tuntutan kuantitas dan kualitas data. Salah satu upaya mewujudkan tata kelola pemerintahan yang baik adalah dengan modernisasi pelayanan publik pada setiap lembaga pemerintahan. Modernisasi pelayanan publik dapat dilakukan melalui implementasi e-Government guna mengkomunikasikan informasi secara dua arah yakni pemerintah, masyarakat maupun dunia usaha (Hardiyansyah, 2018)

Menjawab hal tersebut, Pemerintah melalui Kementerian Agraria dan Tata Ruang/Badan Pertanahan Nasional (ATR/BPN) melakukan peningkatan modernisasi pelayanan pertanahan guna menyesuaikan perkembangan hukum serta teknologi. Secara konkret, Kementerian ATR/BPN meluncurkan program modernisasi layanan pertanahan yang dinamakan Layanan Pertanahan Terintegrasi Secara Elektronik. Pada salah satu wawancara dengan siaran televisi, Menteri ATR/Kepala BPN, Sofyan A. Djalil (2019) menyampaikan bahwa dilaksanakannya HT-el tersebut telah mengurangi antrian masyarakat di Kantor Pertanahan yang menjadi pilot project pelaksanaan HTel. Pernyataan Menteri ATR/BPN dipaparkan kembali pada rapat kerja nasional Kementerian ATR/BPN tahun 2020 dalam bentuk roadmap visi Kementerian ATR/BPN. Program prioritas dalam transformasi digital diuraikan bahwa salah satu target pada tahun 2020 adalah penerapan tanda tangan digital dan sertipikat hak tanggungan elektronik secara nasional. Terdapat 42 kantor pertanahan yang menjadi lokasi pilot project pelaksanaan HT-el yang dimulai sejak September 2019. Instansi pemerintah dalam menetapkan suatu Pilot Project merupakan suatu upaya uji coba implementasi sistem terkait dengan melihat pelaksanaan unit kerja tersebut untuk menjadi percontohan bahkan bila perlu dilakukan pengembangan tertentu sebagai upaya penyempurnaannya.(Setiawan \& Emirsa, 2014)

Pemanfaatan teknologi dan informasi harus dilaksanakan secara maksimal, sehingga Kementerian ATR/BPN harus menjamin bahwa pelaksanaan atau implementasi. Menurut Setiawan dalam (Prafitasari, 2016) implementasi merupakan proses interaksi yang memerlukan penyesuaian antara tujuan dan tindakan dari pelaksana birokrasi yang efektif untuk mencapai tujuannya. Implementasi yang dimaksudkan dalam penelitian ini adalah penerapan peraturan perundangundangan yang terkait dengan pemeliharaan data pertanahan berupa hak tanggungan yang telah terintegrasi secara elektronik.

Kebijakan HT-el telah memenuhi standar prosedur atau mekanisme yang diatur dalam Peraturan Menteri ATR/BPN Nomor 9 Tahun 2019 tentang Pelayanan Hak Tanggungan Terintegrasi Secara Elektronik, yang pada tanggal 6 April 2020 peraturan tersebut dicabut dan diganti menjadi 
Peraturan Menteri ATR/BPN Nomor 5 Tahun 2020 tentang Pelayanan Hak Tanggungan Terintegrasi Secara Elektronik. Hal ini dilakukan sebagai bentuk suatu upaya untuk mencapai meningkatkan pelayanan yang lebih optimal lagi dalam pelaksanaan penyelenggaraan sistem HT-el. Implementasi penggunaan sistem HT-el akan menghasilkan suatu identifikasi kesesuaian antara pelaksanaan di lapangan dengan peraturan perundang-undangan yang berlaku.

Menurut (Mustofa \& Aditya, 2009) suksesnya pelayanan publik di bidang pertanahan yang dilakukan oleh Kementerian ATR/BPN tidak bisa terlepas dari organisasi-organisasi lain sebagai mitra yang saling mendukung dan saling terkait. Wujud kerja sama Kantor Pertanahan Kota Batam terhadap mitra kerja yang terkait dalam penerbitan HT-el ini adalah dengan menyediakan sistem layanan terintegrasi yang dapat diakses oleh kreditor dan PPAT sebagai pengguna layanan HT-el. Kegiatan HT-el diimplementasikan mulai dari verifikasi dan validasi akun pengguna sebagai mitra kerja Kementerian ATR/BPN, proses pendaftaran sampai penerbitan HT-el, sehingga dengan hadirnya layanan terintegrasi tentu akan meniadakan proses interaksi langsung antara pengguna layanan dan pelaksana layanan hak tanggungan. Oleh karena itu, peran Kantor Pertanahan termasuk kreditor dan PPAT sangat penting dalam menyukseskan seluruh pelaksanaan layanan HTel di Kota Batam.

Beberapa penelitian mengenai HT-el, antara lain adalah penelitian yang dilakukan oleh (Nadira, 2019) mengenai pengenalan terobosan baru HT-el dan keterlibatan pihak yang disebut tiga pilar. Adapun yang difokuskan dalam penelitian ini adalah implementasi pelayanan HT-el dengan menguraikan faktor pendukung berupa kesesuaian pelaksanaan dan faktor penghambat berupa kendala yang dihadapi, baik oleh pelaksana maupun pengguna layanan tersebut guna dilakukannya perbaikan untuk mencapainya Visi Kementerian ATR/BPN tersebut. Penelitian mengenai HT-el juga dilakukan oleh Nurwulan (2020), yang meneliti pelaksanaan Hak tanggungan Elektronik dari perspektif hukum. Persoalan krusial yang teridentifikasi dalam penelitian ini adalah kendala pada sistem TI dan server dari HT el. (Nurwulan, 2021)

Berdasarkan uraian di atas, maka melalui penelitian ini perlu dilakukan untuk diketahui kesesuaian pelaksanaan HT-el terhadap peraturan yang menjadi dasar hukumnya. Selain itu, perlu diketahui apa kendala dan bagaimana upaya yang dilakukan oleh Kantor Pertanahan Kota Batam dalam implementasi HT-el tersebut.

\section{B. Metode}

Metode yang digunakan untuk meneliti pelaksanaan HT-el ini adalah penelitian kualitatif dengan pendekatan deskriptif. Metodologi kualitatif sebagai prosedur penelitian yang menghasilkan data deskriptif berupa kata-kata tertulis atau lisan yang dapat diamati (Creswell, 2014; Moleong, 2012). Sedangkan deskriptif adalah bahwa peneliti menggambarkan secara tepat mengenai bentuk, cara, proses yang sesuai dengan kondisi senyatanya di lapangan (Mardalis, 2014).

Metode deskriptif kualitatif dipilih untuk dapat mendeskripsikan kesesuaian pelaksanaan HTel di Kantor Pertanahan Kota Batam dengan Peraturan Menteri ATR/BPN Nomor 5 Tahun 2020 tentang Pelayanan Hak Tanggungan Terintegrasi secara Elektronik, secara detail sekaligus merekam kesulitan atau kendala muncul di lapangan pada saat pelayanan HT elektronik ini diberlakukan. Hasil penelitian ini dapat menjadi pembelajaran (lesson learn) bagi penyelenggaraan HT-el di Kantor 
Pertanahan lain mengingat Kantor Pertanahan Kota Batam termasuk kantor yang paling awal menyelenggarakan layanan Hak Tanggungan elektronik ini. Adapun pengumpulan data dan analisisnya disajikan sebagai berikut:

Gambar 1. Bagan Alir Penelitian

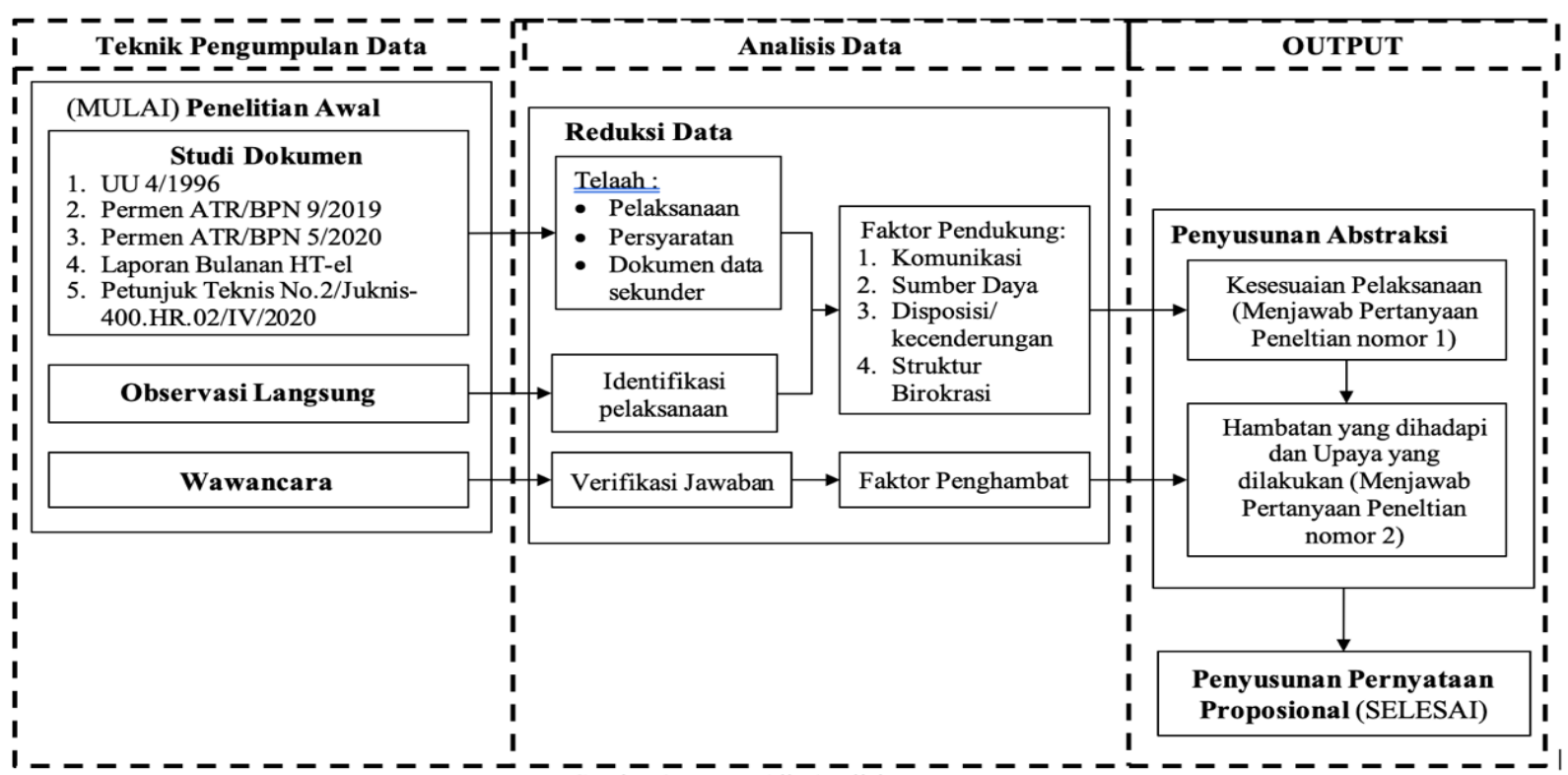

\section{Perbandingan Pelaksanaan HT secara Konvensional dan Elektronik}

Pelaksanaan pelayanan Hak Tanggungan diatur dalam Undang-Undang Nomor 4 Tahun 1996 namun tidak memiliki peraturan pelaksanaan atau petunjuk teknis. Kementerian ATR/BPN menerbitkan kebijakan yang mengatur pelaksanaan Hak Tanggungan dalam upaya peningkatan kualitas dan transformasi digital dengan pelayanan yang telah terintegrasi secara elektronik. Dalam pelaksanaan HT-el diatur dalam Peraturan Menteri ATR/Kepala BPN Nomor 9 Tahun 2019. Kebijakan tersebut kemudian dicabut dan digantikan menjadi Peraturan Menteri ATR/Kepala BPN Nomor 5 Tahun 2020. Berdasarkan peraturan tersebut, selanjutnya dikeluarkan Petunjuk Teknis Nomor 2/Juknis-400.HR.02/IV/2020 (selanjutnya disebut Juknis 2/2020). Berikut perbandingan berdasarkan peraturan antara pelayanan HT konvensional dan HT-el.

Tabel 1. Perbandingan Pelaksanaan Layanan HT konvensional dengan HT Elektronik

\begin{tabular}{|c|c|c|c|c|}
\hline \multirow[t]{2}{*}{ No } & \multirow{2}{*}{$\begin{array}{l}\text { Aspek yang } \\
\text { dibandingkan }\end{array}$} & \multirow[t]{2}{*}{ Konvensional } & \multicolumn{2}{|c|}{ Layanan Elektronik } \\
\hline & & & Permen No 9/2019 & Permen no 5/2020 \\
\hline 1 & Petunjuk Teknis & Tidak ada & Tidak Ada & Juknis No 2/2020 \\
\hline 2 & $\begin{array}{l}\text { Wujud } \\
\text { Sertifikat }\end{array}$ & $\begin{array}{l}\text { Fisik, blanko } \\
\text { disediakan oleh } \\
\text { Kementerian ATR/BPN }\end{array}$ & $\begin{array}{l}\text { Dicetak oleh Kreditor } \\
\text { (Tidak ada pengaturan) }\end{array}$ & $\begin{array}{l}\text { Dikirim ke email dan } \\
\text { dicetak kreditor (diatur } \\
\text { dalam Juknis) }\end{array}$ \\
\hline 3 & $\begin{array}{l}\text { Catatan Buku } \\
\text { Tanah }\end{array}$ & $\begin{array}{l}\text { Dilakukan oleh } \\
\text { petugas Kantor } \\
\text { Pertanahan }\end{array}$ & $\begin{array}{l}\text { Dicetak sendiri oleh } \\
\text { Kreditor melalui Sistem } \\
\text { (belum dijelaskan) }\end{array}$ & $\begin{array}{l}\text { Dikirim kepada email } \\
\text { Kreditor dan dicetak pada } \\
\text { Kertas stiker warna putih } \\
\text { polos (diatur dalam } \\
\text { Juknis) }\end{array}$ \\
\hline 4 & $\begin{array}{l}\text { Lama } \\
\text { pelayanan }\end{array}$ & Tidak diatur & Tidak diatur & $\begin{array}{l}\text { Pasal } 1 \text { ayat } 17: \text { Hari } \\
\text { adalah hari kalender }\end{array}$ \\
\hline
\end{tabular}




\begin{tabular}{|c|c|c|c|c|}
\hline 5 & $\begin{array}{l}\text { Jenis layanan } \\
\text { HT Elektronik }\end{array}$ & $\begin{array}{l}\text { pendaftaran, } \\
\text { peralihan, perubahan } \\
\text { nama kreditor, roya }\end{array}$ & $\begin{array}{l}\text { Pasal 6: pendaftaran, } \\
\text { peralihan, perubahan nama } \\
\text { kreditor, penghapusan }\end{array}$ & $\begin{array}{l}\text { Ditambah dengan } \\
\text { perbaikan data (Pasal } 6 \\
\text { ayat 1) }\end{array}$ \\
\hline 6 & Kreditor & $\begin{array}{l}\text { Sesuai peraturan } \\
\text { perundangan }\end{array}$ & $\begin{array}{l}\text { Telah menjadi pengguna } \\
\text { terdaftar }\end{array}$ & $\begin{array}{l}\text { Sesuai dengan peraturan } \\
\text { perundang-undangan } \\
\text { (Pasal 7) }\end{array}$ \\
\hline 7 & Debitor & Sesuai peraturan & $\begin{array}{l}\text { Pasal } 9 \text { ayat } 5 \text { debitor sama } \\
\text { dengan nama pemilik } \\
\text { sertipikat }\end{array}$ & $\begin{array}{l}\text { tidak diatur lagi harus } \\
\text { sesuai dengan nama pada } \\
\text { sertipikat }\end{array}$ \\
\hline 8 & PPAT & $\begin{array}{l}\text { Mengantar APHT dan } \\
\text { dokumen lain ke } \\
\text { Kantor Pertanahan }\end{array}$ & $\begin{array}{l}\text { Pasal } 10 \text { PPAT hanya } \\
\text { menyampaikan APHT } \\
\text { melalui sistem HT-el }\end{array}$ & $\begin{array}{l}\text { Pasal } 9 \text { dijelaskan tupoksi } \\
\text { PPAT dan Kreditor dalam } \\
\text { HT-el secara jelas }\end{array}$ \\
\hline 9. & $\begin{array}{l}\text { Waktu } \\
\text { Melengkapi } \\
\text { Berkas }\end{array}$ & Tidak dijelaskan & Tidak dijelaskan & $\begin{array}{l}\text { Pasal } 13 \text { dijelaskan paling } \\
\text { lama hari ke } 5 \text { sejak } \\
\text { permohonan diterima } \\
\text { sistem }\end{array}$ \\
\hline 10 & $\begin{array}{l}\text { Pemeriksaan } \\
\text { berkas }\end{array}$ & Tidak dijelaskan & Belum dijelaskan & Pasal 14 sampai hari ke-7 \\
\hline 11. & $\begin{array}{l}\text { Penundaan } \\
\text { Layanan }\end{array}$ & $\begin{array}{l}\text { Dilakukan secara } \\
\text { manual dengan } \\
\text { menghubungi } \\
\text { pemohon }\end{array}$ & $\begin{array}{l}\text { Pasal } 23 \text { ditunda terlebih } \\
\text { dahulu, jika lebih dari } 7 \\
\text { hari baru dibatalkan secara } \\
\text { otomatis }\end{array}$ & $\begin{array}{l}\text { Pasal } 24 \text { dapat langsung } \\
\text { ditolak/dibatalkan secara } \\
\text { otomatis }\end{array}$ \\
\hline
\end{tabular}

Sumber: Pengolahan Data Primer Penelitian, 2020

Dari Tabel 1 di atas dapat dilihat awalnya seluruh Hak Tanggungan dilaksanakan secara manual, namun sejak terbitnya kebijakan mengenai penggunaan HT-el, permohonan berkas berjalan secara otomatis sesuai dengan sistem yang ada. Pada HT konvensional debitor tidak membatasi dan dapat dikuasakan, sementara pelaksanaan HT-el pada Pasal 9 ayat (5) Peraturan Menteri ATR/Kepala BPN Nomor 9 Tahun 2019 menyebutkan persyaratan berupa Sertipikat Hak Atas Tanah atau Hak Milik Atas Satuan Rumah Susun harus atas nama debitor. Hal ini mengakibatkan Kantor Pertanahan Kota Batam masih melaksanakan pelayanan pertanahan HT secara konvensional untuk nama pemilik sertipikat hak atas tanah yang tidak sama dengan calon debitornya. Setelah dikeluarkan Peraturan Menteri ATR/Kepala BPN Nomor 5 Tahun 2020 tidak ada disebutkan lagi mengenai pembatasan debitor dan kreditor, sehingga HT-el dapat dilakukan untuk seluruh pelayanan HT dan meniadakan layanan HT konvensional. Pelaksanaan HT secara konvensional hanya berlaku hingga 3 bulan setelah dikeluarkan peraturan perundang-undangan tersebut dan mewajibkan diterapkannya pelayanan HT-el secara nasional di seluruh Kantor Pertanahan yaitu pada tanggal 8 Juli 2020.

Pengguna layanan yaitu PPAT dan Kreditor, juga dapat merasakan secara langsung beberapa perbedaan secara signifikan dalam pelaksanaan HT konvensional dengan elektronik, antara lain sebagai berikut.

Tabel 2. Perbedaan Layanan HT Konvensional dengan HT Elektronik berdasarkan Persepsi Pengguna Sistem

\begin{tabular}{|c|c|c|c|}
\hline No & Aspek yang dibandingkan & $\begin{array}{c}\text { Layanan HT } \\
\text { Konvensional }\end{array}$ & Layanan HT Elektronik \\
\hline 1 & $\begin{array}{l}\text { Interaksi petugas kantor } \\
\text { dan pemohon }\end{array}$ & $\begin{array}{l}\text { Interaksi fisik secara } \\
\text { langsung }\end{array}$ & Interaksi melalui sistem \\
\hline 2 & Waktu Layanan & 4 hari, pada jam kantor & Tidak terbatas, bahkan pada hari libur \\
\hline
\end{tabular}


3

Berkas kelengkapan

$4 \quad$ Waktu yang diperlukan

5 Penyerahan hasil

Proses pembebanan HT

7

Warkah
Berkas fisik berupa

fotokopi dan asli

7 hari atau lebih

Diserahkan secara fisik

pada loket penyerahan

sertipikat HT

Diberikan catatan

langsung pada fisik

sertifikat hak atas tanah

Warkah disimpan secara

fisik di ruang

penyimpanan warkah
Data Digital hasil scan

7 hari persis

Sertifikat Digital dikirim melalui email pemohon

Catatan diberikan secara terpisah dari sertifikat dan dikirimkan melalui email, dicetak dan dirangkaikan dengan sertifikat hak atas tanah secara terpisah Tersimpan secara digital pada sistem

Sumber: Hasil Wawancara dengan pengguna sistem HT-el

Dari perbandingan di atas, menunjukkan bahwa HT-el merupakan inovasi yang sangat efisien baik dari segi waktu hingga penyimpanan produk yang dihasilkan. Namun, untuk pelayanan permohonan di Kantor Pertanahan Kota Batam masih menggunakan HT Konvensional karena tingginya permohonan dari debitor dengan penjamin yang berbeda.

\section{Implementasi Layanan HT-el}

Implementasi layanan HT-el terdiri dari 3 tahap, yaitu persiapan, pelaksanaan dan evaluasi.

1. Persiapan Pelaksanaan HT-el

Tapan persiapan persiapan dalam pelaksanaan HT-el meliputi pekerjaan validasi data, pendaftaran akun, dan pendaftaran tanda tangan elektronik. Kesalahan utama yang dapat terjadi dalam pelayanan HT-el adalah jika data tekstual dan data spasial bidang tanah pada KKP belum divalidasi keseluruhannya secara lengkap. Kantor Pertanahan Kota Batam telah melakukan persiapan berupa validasi data terhadap bidang-bidang tanah terdaftar yang ada di Kantor Pertanahan. Sebagai salah satu pilot project kantor yang menjadi percontohan awal terhadap layanan HT-el ini, Kantor Pertanahan Kota Batam telah melakukan proses validasi data keseluruhan lebih awal sebelum dikeluarkannya kebijakan pelayanan pertanahan HT-el ini. Dari data primer yang dilakukan melalui wawancara kepada Kepala Subseksi Pendaftaran Hak Tanah Kantor Pertanahan Kota Batam menjelaskan, bahwa untuk data tekstual yang belum lengkap, dilakukan buka validasi buku tanah oleh admin KKP di Kantor Pertanahan. Setelah itu, dilakukan pengisian data tekstual sebagaimana dengan yang ada pada buku tanah dan data spasial sebagaimana yang ada pada surat ukur bidang tanah tersebut. Terakhir dilakukan validasi ulang pada KKP untuk dilakukan penyimpanan. Pentingnya perbaikan dan perlengkapan data elektronik ini menjadi pegangan utama karena hasil dari validasi tersebut memiliki kekuatan hukum yang sama dengan dokumen tercetak manual.

Selanjutnya dilakukan pendaftaran akun yang wajib dimiliki oleh petugas di Kantor Pertanahan, PPAT dan Kreditor. Untuk Kantor Pertanahan yang wajib memiliki akun adalah Kepala Kantor, Kepala Seksi, Kepala Subseksi, atau pejabat fungsional yang menangani Hak Tanggungan serta menunjuk ASN ataupun PPNPN untuk menjadi admin verifikator. Sedangkan untuk PPAT, akun didaftarkan melalui aplikasi Mitra Kerja dengan mengisi formulir dan melengkapi persyaratan, dan menunggu verifikasi dari Kantor Pertanahan pada wilayah kerjanya. 
Tahap selanjutnya adalah pendaftaran tanda tangan elektronik bagi Kepala Kantor atau pejabat yang ditunjuk untuk mengesahkan sertipikat HT-el. penerapan TTE pada layanan pertanahan di Kementerian ATR/BPN telah diatur dalam Peraturan Menteri ATR/Kepala BPN Nomor 3 Tahun 2019 tentang Penerapan Tanda Tangan Elektronik. Pendaftaran TTE ini dilakukan oleh Kepala Kantor atau pejabat struktural maupun fungsional yang dilimpahkan kewenangan untuk mengesahkan yang akan menandatangani Sertipikat HT-el. Kewenangan tersebut dapat diberikan kepada lebih dari satu orang dengan pertimbangan terhadap volume pekerjaan. Pada pelaksanaannya, Kantor Pertanahan Kota Batam terdapat sebanyak 3 TTE yang aktif yaitu, Kepala Kantor, Kepala Seksi Hubungan Hukum Pertanahan dan Kepala Subseksi Pendaftaran Hak Tanah.

2. Pelaksanaan HT-el

HT-el di Kantor Pertanahan Kota Batam telah dilaksanakan sejak tanggal bulan September 2019. Sedangkan pedoman untuk pelaksanaan HT-el diatur pada Juknis 2/2020 tanggal 29 April 2020 tentang Pelayanan Hak Tanggungan Terintegrasi secara Elektronik. Dalam masa peralihan dari konvensional menuju elektronik, pada Peraturan Menteri ATR/Kepala BPN Nomor 9 Tahun 2019 HTel hanya dapat diajukan oleh debitor yang sertipikat hak atas tanahnya merupakan nama bersangkutan saja. Namun, dikarenakan layanan ini akan direalisasikan untuk seluruh layanan Hak Tanggungan, yang artinya peniadaan layanan konvensional, maka dikeluarkanlah Peraturan Menteri ATR/Kepala BPN Nomor 5 Tahun 2020 yang selanjutnya dilengkapi dengan Juknis 2 Tahun 2020.

Jenis pelayanan hak tanggungan yang dapat diajukan melalui sistem HT-el adalah pendaftaran Hak Tanggungan, peralihan Hak Tanggungan, perubahan nama Kreditor, penghapusan Hak Tanggungan, dan perbaikan data. Objek Hak Tanggungan dapat dibebankan pada hak milik, hak guna usaha dan hak guna bangunan maupun hak pakai sesuai dengan peraturan perundangundangan yang berlaku. Setelah akun Mitra Kerja telah diverifikasi, PPAT dapat masuk/login melalui https://mitra.atrbpn.go.id dengan memasukkan user name dan password.

Sertipikat yang akan dibebankan HT oleh debitor terlebih harus dicek melalui layanan pengecekan sertipikat yang dilakukan oleh PPAT dengan menggunakan menggunakan Aplikasi Mitra Kerja maupun secara manual sesuai dengan ketersediaan data elektronik dari Kantor Pertanahan. Selanjutnya, PPAT dapat membuat APHT dengan memasukkan secara elektronik data serta kelengkapan berkas. PPAT akan mengisi data akta secara lengkap serta menyiapkan persyaratan pendaftaran HT dan surat pengantar PPAT yang telah di scan dalam bentuk file format .pdf dengan resolusi minimal $100 \mathrm{dpi}$. File tersebut kemudian diunggah sesuai dengan kolom form yang tertera pada tampilan pada menu pembuatan APHT. Bila terjadi renvoi PPAT wajib melakukan upload ulang sebelum didaftarkan pada Sistem HT-el oleh Kreditor. Setelah mendapatkan Salinan APHT, kreditor dapat memohonkan berkas tersebut pada pelayanan HT-el dengan mengakses dan login akun melalui https://htel.atrbpn.go.id. Permohonan diajukan dengan mencari nomor dan kode akta yang termuat pada surat pengantar akta. Adapun persyaratan yang harus diupload selain APHT adalah sebagai berikut; (1) NPWP Debitor Perorangan/Badan Hukum; (2) KTP Saksi Pembuatan APHT; (3) KTP Pihak Persetujuan (jika ada), jika tidak ada maka mengunggah surat pernyataan tidak memerlukan persetujuan; (4) SPPT PBB; (5) Sertipikat Hak Atas Tanah atau HM Sarusun; (6) Surat Kuasa Membebankan Hak Tanggungan; dan (7) Formulir pernyataan dan pertanggungjawaban keabsahan dan kebenaran dokumen. 
Kemudian Kreditor menyesuaikan data dokumen permohonan pendaftaran $\mathrm{HT}$ yang diunggah oleh PPAT serta melengkapi jika masih ada yang dibutuhkan (scan dalam bentuk file format .pdf). Dokumen yang harus diunggah oleh Kreditor, yaitu; 1) Surat Permohonan; 2) Akta Pendirian Kreditor; 3) KTP Operator Kreditor; 4) NPWP Kreditor; 5) SK Pengangkatan; dan 6) Surat Penunjukan.

Setelah di input, sistem HT-el akan mengeluarkan Surat Perintah Setor (SPS) biaya pelayanan yang wajib dibayar oleh Kreditor paling lambat 3 hari dan apabila melewati jangka waktu tersebut sistem tidak menerima konfirmasi pembayaran, maka berkas akan dibatalkan secara otomatis oleh sistem. Kreditor harus kembali melakukan permohonan baru jika berkas telah dibatalkan. Sistem HT-el akan menghitung jangka waktu berkas dimulai sejak pembayaran terkonfirmasi. Hitungan hari dalam pelaksanaan HT-el ini merupakan hari kalender. Jika terdapat ketidaksesuaian dokumen permohonan tersebut, maka petugas dapat meminta pengguna layanan untuk melengkapinya. Sistem HT-el akan mengirimkan melalui email sesuai data akun untuk pemberitahuan tersebut. Jangka waktu paling lama adalah pada hari ke-5 sejak berkas dimulai. Jika tidak melengkapi, maka berkas tersebut akan dibatalkan secara otomatis. Namun apabila berkas permohonan telah sesuai maka selanjutnya akan diteruskan kepada pejabat yang telah ditunjuk dan Kepala Kantor untuk disahkan dengan TTE di Sertipikat HT-el tersebut.

Sistem HT-el akan melanjutkan proses permohonan pelayanan yang telah dikonfirmasi pembayarannya sampai dengan penerbitan Sertipikat HT-el secara otomatis pada hari ke-7. Sehingga meskipun petugas dan pejabat di Kantor Pertanahan tidak melakukan pemeriksaan terhadap berkas tersebut, sistem tetap akan menerbitkan Sertipikat HT-el dan Kepala Kantor bertanggung jawab atas produk yang telah diterbitkan. Hal ini berarti, baik Kantor Pertanahan maupun pengguna layanan harus berperan aktif dan tanggap terhadap penyelenggaraan layanan HT-el ini.

Selain Sertipikat HT-el, hasil dari Pelayanan HT-el adalah catatan HT. Catatan HT yang ada pada buku tanah elektronik akan dikirim melalui email kepada Kreditor, yang kemudian harus ditempelkan pada Sertipikat Hak Tanah yang menjadi objek HT dengan menggunakan kertas stiker berwarna putih polos. Kreditor berkewajiban untuk memeriksa hasil layanan meliputi; (1) Kode Sertipikat; (2) Nomor DI 208; (3) Edisi; (4) Nomor Hak Tanggungan; (5) Peringkat; (6) Nilai Hak Tanggungan; (7) Pemegang Hak Tanggungan; (8) Jenis dan nomor hak beserta benda lain; dan (9) Tanda Tangan Elektronik pada Sertipikat HT-el yang telah terbit. Apabila terdapat kesalahan data yang tertera, Kreditor dapat mengajukan permohonan perbaikan data dengan jangka waktu 30 hari kalender sejak HT terbit. Namun, jika telah sesuai Kreditor diwajibkan untuk mencetak dan menempelkan catatan HT-el pada Sertipikat sesuai dengan ketentuan yang berlaku, yaitu dicetak pada kertas stiker berwarna putih polos dan ditempel pada baris akhir dari catatan terakhir pada Sertipikat tersebut.

\section{Evaluasi Pelaksanaan HT-el}

Evaluasi terhadap pelaksanaan HT-el di Kantor Pertanahan Kota Batam, belum dapat dilaksanakan pada saat penelitian ini laksanakan oleh karena baru dilaksanakan selama kurang lebih 3 bulan dengan perubahan peraturan dari Peraturan Menteri ATR/Kepala BPN Nomor 9 Tahun 2019 diganti menjadi Peraturan Menteri ATR/Kepala BPN Nomor 5 Tahun 2020. 


\section{E. Analisis Kesesuaian Pelaksanaan HT-el terhadap Peraturan Menteri ATR/BPN Nomor 5 Tahun 2020}

Meskipun masih dalam masa pengembangan, baik dari segi peraturan, juknis maupun sistemnya, Kantor Pertanahan Kota Batam telah melaksanakan seluruh tahapan yang ada, sebagaimana yang telah diatur dalam perundangan yang berlaku dengan sangat baik. Hal ini dibuktikan dengan menjadi salah satu Kantor Pertanahan yang memiliki jumlah permohonan terbanyak pada pilot project tahun 2019. Sertipikat HT-el yang telah diterbitkan oleh Kantor Pertanahan Kota Batam melalui pelayanan sistem HT-el sejak diselenggarakan pada bulan September 2019 sampai dengan tanggal 30 April 2020 adalah sebanyak 3.790 buah sertipikat Hak Tanggungan. Adapun realisasi jumlah permohonan pelayanan pertanahan Hak Tanggungan, baik secara konvensional maupun yang masuk melalui sistem HT-el dapat dilihat pada tabel berikut.

Tabel 3 . Jumlah Permohonan Pelayanan Hak Tanggungan s.d. April 2020 di Kantor Pertanahan Kota Batam

\begin{tabular}{|c|c|c|c|c|c|}
\hline \multirow[t]{2}{*}{ No } & \multirow[t]{2}{*}{ Bulan } & \multicolumn{3}{|c|}{ Hak Tanggungan } & \multirow{2}{*}{$\begin{array}{l}\text { Jumlah } \\
\text { Permohonan } \\
\text { (berkas) }\end{array}$} \\
\hline & & HT Konvesional (berkas) & $\begin{array}{c}\text { HT-el } \\
\text { (berkas) }\end{array}$ & $\begin{array}{c}\% \\
\text { HT-el }\end{array}$ & \\
\hline 1 & Agustus 2019 & 1.304 & - & & 1.304 \\
\hline 2 & September 2019 & 1323 & 29 & 2,14 & 1.352 \\
\hline 3 & Oktober 2019 & 701 & 409 & 36,85 & 1.110 \\
\hline 4 & November 2019 & 418 & 517 & 55,29 & 935 \\
\hline 5 & Desember 2019 & 338 & 615 & 64,53 & 953 \\
\hline 6 & Januari 2020 & 177 & 574 & 76,43 & 751 \\
\hline 7 & Februari 2020 & 160 & 507 & 76,01 & 667 \\
\hline 8 & Maret 2020 & 244 & 636 & 72,27 & 880 \\
\hline \multirow[t]{2}{*}{9} & April 2020 & 69 & 503 & 87,94 & 572 \\
\hline & Jumlah & 4.734 & 3.790 & & 8.527 \\
\hline
\end{tabular}

Sumber: Pengolahan Data Primer Peneliti, 2020

Dari Tabel 3 di atas, dapat dilihat bahwa terdapat penurunan jumlah permohonan Hak Tanggungan jika dibandingkan antara sebelum dan sesudah menggunakan HT-el. Akan tetapi, penurunan ini terjadi bukan disebabkan karena adanya sistem HT-el, melainkan pendaftar Hak Tanggungannya yang menurun dan tergantung pada kondisi serta pola perekonomian masyarakat Kota Batam yang membutuhkan jaminan sebagai debitor. Pada Tabel 7 diuraikan permohonan pelayanan pertanahan berupa Hak Tanggungan yaitu, pada tahun 2017 sebanyak 12.706 permohonan, tahun 2018 sebanyak 11.900 permohonan dan tahun 2019 sebanyak 13.261 permohonan. Sehingga jumlah Hak Tanggungan yang menurun bukan disebabkan oleh Sistem HTel. Sejak bulan November 2019, tercatat bahwa jumlah permohonan HT menggunakan sistem HT-el mengalami peningkatan jika dibandingkan dengan HT Konvensional. Hal ini menunjukkan bahwa, pelayanan HT-el di Kantor Pertanahan Kota Batam dapat digunakan dengan baik. Pada bulan April persentase sistem HT-el adalah 87,94\% dari 572 berkas permohonan Hak Tanggungan.

Tahap persiapan yang dilakukan oleh Kantor Pertanahan Kota Batam sebelum diselenggarakannya HT-el adalah dengan melakukan validasi seluruh data tekstual dan spasial terhadap data yang belum lengkap. Kantor Pertanahan Kota Batam juga telah melaksanakan sosialisasi bagi PPAT dan Kreditor yang telah melakukan pendaftaran akun, baik berupa sosialisasi secara tatap muka maupun berupa melalui buku panduan.

Untuk pemeriksaan berkas permohonan, Kantor Pertanahan Kota Batam memiliki 4 buah akun yaitu kepala kantor, pejabat yang berwenang dan verifikator. Sedangkan untuk pengesahannya 
didaftarkan 3 buah TTE sebagai pelimpahan kewenangan dari Kepala Kantor. Sistem HT-el yang terintegrasi ini mengharuskan seluruh pengguna untuk aktif dan responsif terhadap informasi yang masuk melalui email, baik tentang kelengkapan berkas maupun informasi lainnya.

Pada pelaksanaannya, sistem HT-el di Kantor Pertanahan Kota Batam pernah menerbitkan Sertipikat HT-el tanpa melalui pemeriksaan berkas sebelumnya. Berkas tanpa pemeriksaan merupakan berkas yang telah diterbitkan Sertipikat HT setelah 7 hari dari konfirmasi berkas masuk diterima oleh sistem HT-el, namun petugas pelaksana di Kantor Pertanahan tidak melakukan pemeriksaan terhadap berkas tersebut hingga jangka waktu penyelesaian pelayanan berakhir. Terdapat 18 Sertipikat HT-el yang diterbitkan tanpa dilakukan pemeriksaan. Berikut tabel rekapitulasinya.

Tabel 4. Rekapitulasi Berkas Tanpa Pemeriksaan s.d April di Kantor Pertanahan Kota Batam

\begin{tabular}{clc}
\hline No & \multicolumn{1}{c}{ Bulan } & Jumlah Berkas \\
\hline 1 & September 2019 & 5 \\
2 & Oktober 2019 & 3 \\
3 & November 2019 & 5 \\
4 & Desember 2019 & 3 \\
5 & Januari 2020 & 1 \\
6 & Pebruari 2020 & 1 \\
7 & Maret 2020 & 0 \\
8 & April 2020 & 0 \\
\hline
\end{tabular}

Sumber: Pengolahan Data Primer Peneliti, 2020

Dari Tabel 4 di atas dapat dilihat bahwa berkas tanpa pemeriksaan paling banyak terjadi pada bulan September 2019 dan November 2019. Namun terjadi penurunan jumlah hingga tidak ada lagi Sertipikat HT-el yang terbit tanpa pemeriksaan. Hal ini dikarenakan permulaan dari suatu pelaksanaan pelayanan pertanahan yang baru, dimana petugas masih beradaptasi dan mempelajari lebih lanjut mekanismenya. Selain itu, tidak sebandingnya antara jumlah SDM dengan kuantitas pekerjaan yang tinggi menjadi faktor lainnya. Kantor Pertanahan Kota Batam telah mengantisipasi agar hal ini tidak terjadi lagi, yaitu dengan menambah 3 orang petugas untuk melakukan pengecekan terhadap berkas permohonan yang masuk. Tugasnya untuk melakukan pengecekan pelayanan HT-el setiap hari terhadap berkas baru masuk maupun berkas yang sedang diproses agar tidak terjadi kesalahan-kesalahan yang disebabkan dari petugas Kantor Pertanahan.

Terdapat pula penutupan terhadap beberapa berkas permohonan HT yang telah terima oleh sistem HT-el di karena berkas belum diperbaiki atau belum lengkap. Berikut tabel rekapitulasi berkas HT-el yang ditutup di Kantor Pertanahan Kota Batam.

Tabel 5. Rekapitulasi Berkas HT -el s.d. April 2020 di Kantor Kota Batam

\begin{tabular}{cccl}
\hline No & Bulan & Jumlah (berkas) & \multicolumn{1}{c}{ Keterangan } \\
\hline 1 & Oktober 2019 & 10 & $\begin{array}{l}\text { Seluruhnya ditutup karena berkas belum diperbaiki } \\
\text { melebihi batas waktu penerbitan }\end{array}$ \\
2 & November 2019 & 11 & $\begin{array}{l}\text { Seluruhnya ditutup karena berkas belum diperbaiki } \\
\text { melebihi batas waktu penerbitan }\end{array}$ \\
3 & Desember 2019 & 6 & $\begin{array}{l}\text { Seluruhnya ditutup karena berkas belum diperbaiki } \\
\text { melebihi batas waktu penerbitan } \\
\text { Seluruhnya ditutup karena berkas belum diperbaiki } \\
\text { melebihi batas waktu penerbitan }\end{array}$ \\
\hline
\end{tabular}




\begin{tabular}{cccl}
\hline 5 & Februari 2020 & 22 & $\begin{array}{l}1 \text { berkas ditutup karena berkas sudah punya kode } \\
\text { billing tapi belum dibayar }\end{array}$ \\
6 & Maret 2020 & $\begin{array}{l}\text { Seluruhnya ditutup karena berkas belum diperbaiki } \\
\text { melebihi batas waktu penerbitan }\end{array}$ \\
7 & April 2020 & 19 & $\begin{array}{l}\text { Seluruhnya ditutup karena berkas belum diperbaiki } \\
\text { melebihi batas waktu penerbitan }\end{array}$ \\
\hline & & $\mathbf{1 0 7}$
\end{tabular}

Sumber: Pengolahan Data Primer Peneliti, 2020

Dari Tabel 5 di atas dapat dilihat bahwa terdapat 107 berkas permohonan yang ditutup. Hal ini penyebab utamanya adalah dari berkas yang telah diperiksa oleh petugas belum sesuai dengan ketentuan, sehingga harus diperbaiki terlebih dahulu oleh pihak Kreditor maupun PPAT. Namun pada pelaksanaannya masih terdapat PPAT atau Kreditor tidak melakukan pengecekan pada email yang digunakan pada akun Mitra Kerja secara rutin hingga melewati batas waktu yang telah ditentukan yaitu 5 hari sejak diterima oleh sistem. Selain itu terdapat 1 berkas yang ditutup karena belum melakukan pembayaran setelah SPS diterima melalui email Kreditor.

Berdasarkan wawancara pada hari Kamis 23 April 2020 pukul 13.10 WIB dengan Kepala Kantor Pertanahan Kota Batam bahwa dalam pelaksanaannya, PPAT telah menyepakati surat komitmen dari Kantor Pertanahan Kota Batam untuk ketersediaannya tanggap mengenai kelengkapan berkas jika pada saat pemeriksaan berkas terdapat berkas yang harus diperbaiki atau dilengkapi. Ini dilakukan untuk meminimalisir penutupan berkas dengan permasalahan kelengkapan berkas berkas. Berdasarkan uraian di atas, kesesuaian implementasi HT-el dengan Peraturan Menteri ATR/Kepala BPN Nomor 5 Tahun 2020 dan Juknis No. 2/2020, dapat dilihat pada tabel berikut.

Tabel 6. Kesesuaian Implementasi HT-el dengan Peraturan Menteri ATR/Kepala BPN Nomor 5 Tahun 2020 di Kantor Pertanahan Kota Batam

\begin{tabular}{|c|c|c|c|c|}
\hline No & Klasifikasi & $\begin{array}{c}\text { Peraturan Menteri } \\
\text { ATR/Kepala BPN No.5 } \\
\text { Tahun } 2020\end{array}$ & $\begin{array}{l}\text { Pelaksanaan HT-el di Kantor } \\
\text { Pertanahan Kota Batam }\end{array}$ & Kesesuaian \\
\hline 1 & Persiapan & Validasi data & Perbaikan data spasial dan atribut & Sesuai \\
\hline \multirow[t]{3}{*}{2} & $\begin{array}{l}\text { Pedaftaran } \\
\text { Akun }\end{array}$ & PPAT & $\begin{array}{l}\text { Terdaftar } 121 \text { akun PPAT terdaftar dan } \\
\text { terverifikasi }\end{array}$ & Sesuai \\
\hline & & Kreditor Badan Hukum & $\begin{array}{l}\text { Kreditor Badan Hukum terdaftar dan } \\
\text { terverifikasi sebanyak } 62 \text { Bank, } \\
\text { sedangkan Kreditor perorangan belum } \\
\text { dapat mendaftarkan akun untuk } \\
\text { mengakses HT-el }\end{array}$ & Sesuai \\
\hline & & $\begin{array}{l}\text { Petugas Kantor } \\
\text { Pertanahan }\end{array}$ & $\begin{array}{l}\text { Terdapat } 4 \text { akun yang terdaftar dalam } \\
\text { sistem HT-el }\end{array}$ & Sesuai \\
\hline 4 & Debitor & $\begin{array}{l}\text { tidak dibatasi siapa } \\
\text { debitor dan penjaminnya }\end{array}$ & $\begin{array}{l}\text { Untuk Debitor dengan penjamin yang } \\
\text { berbeda dengan pemilik Hak Atas } \\
\text { Tanah menggunakan HT Konvensional }\end{array}$ & Tidak Sesuai \\
\hline 5 & $\begin{array}{l}\text { Format file } \\
\text { upload }\end{array}$ & $\begin{array}{l}\text { Resolusi minimal } 100 \mathrm{DPI} \\
\text { dalam format file pdf }\end{array}$ & $\begin{array}{l}\text { Semua berkas yang diupload oleh } \\
\text { PPAT dan Kreditor dalam bentuk pdf } \\
\text { dengan resolusi di atas } 100 \text { DPI dan } \\
\text { dapat dibaca dengan jelas }\end{array}$ & Sesuai \\
\hline 6 & $\begin{array}{l}\text { Tanda } \\
\text { tangan } \\
\text { Elektronik }\end{array}$ & $\begin{array}{l}\text { Pejabat aktif yang } \\
\text { berwenang mengesahkan } \\
\text { hasil Pelayanan HT-el }\end{array}$ & $\begin{array}{l}\text { Kantor Pertanahan Kota Batam } \\
\text { melimpahkan kewenangan }\end{array}$ & Sesuai \\
\hline
\end{tabular}


adalah Kepala Kantor Pertanahan atau pejabat yang diberi pelimpahan

kewenangan. pengesahan sertipikat HT-el kepada

Kasi Hubungan Hukum Pertanahan

\section{Sumber: Pengolahan Data Primer Peneliti, 2020}

Pada saat penelitian ini dilaksanakan, pelaksanaan HT-el sedang pada masa tahap peralihan peraturan yang dari Peraturan Menteri ATR/Kepala BPN Nomor 9 Tahun 2019 menjadi Peraturan Menteri ATR/Kepala BPN Nomor 5 Tahun 2020 yang pelaksanaannya diuraikan dalam Juknis No. 2/2020 yang dikeluarkan setelah peraturan terbaru ditetapkan. Sehingga peneliti hanya dapat menguraikan kesesuaian dengan Peraturan Menteri ATR/Kepala BPN Nomor 5 Tahun 2020, bukan mengevaluasi secara detail sesuai beserta Juknis No. 2/2020 karena pelaksanaan HT-el secara nasional akan sepenuhnya dilaksanakan setelah 3 bulan ditetapkan. Adapun beberapa faktor pendukung yang mempengaruhi kesesuaian pelaksanaan (Tangkilisan, 2005) tersebut, yaitu:

a. Komunikasi

Suatu kebijakan pelayanan pertanahan dimulai dengan melakukan sosialisasi dan komunikasi terlebih dahulu agar dapat meningkatkan komunikasi yang baik antara penyelenggara, pelaksana dan pengguna dengan pelayanan HT-el ini. Kementerian ATR/BPN telah melakukan sosialisasi pelayanan HT-el dengan memilih 42 Kantor Pertanahan yang dijadikan sebagai pilot project yang ditujukan kepada pelaksana dan pengguna HT-el. Kantor Pertanahan yang menjadi pilot project serta pengguna layanan pada wilayah kerja Kantor Pertanahan diberikan pengenalan tentang Sistem HT-el dan informasi kepada seluruh PPAT dan Kreditor mulai melakukan Sistem HT-el pada berkas permohonan HT yang nama debitor sama dengan Sertipikatnya.

Pada masa peralihan dari kegiatan pelayanan konvensional menjadi elektronik, dibutuhkan komunikasi yang baik dengan pihak-pihak yang terlibat dalam pelayanan ini. Sistem yang berjalan secara otomatis ini mengharuskan suatu komunikasi yang aktif antara pelaksana dengan penggunanya. Dimana jika terdapat kekurangan, sistem akan mengirimkan pemberitahuan melalui email. Kantor Pertanahan Kota Batam juga meminta PPAT dan Kreditor berkomitmen untuk segera melengkapi dokumen dan persyaratan jika terdapat kekurangan setelah dilakukannya pemeriksaan berkas. Hal ini karena jika berkas tidak juga dilengkapi hingga hari ke-5, maka akan ditutup secara otomatis dan Kreditor harus mendaftarkan ulang dan pembayaran SPS dengan berkas permohonan yang baru. Sedangkan PNBP yang telah disetor terhadap berkas yang dibatalkan, dapat diajukan pengembalian PNBP tersebut dengan proses dan waktu sesuai dengan peraturan yang berlaku. Namun pada pelaksanaannya, proses pengembalian tersebut belum pada tahap selesai karena masih harus menunggu pengajuan pengembalian PNBP.

Hasil sebagai pilot project HT-el, Kantor Pertanahan Kota Batam merupakan salah satu Kantor Pertanahan yang telah menggunakan Sistem HT-el dengan sangat baik. Hal ini dapat dilihat dari hasil persentase pelayanan HT-el yang semakin meningkat dari pada konvensional, juga berada pada posisi 5 Kantor Pertanahan dengan permohonan HT-el terbanyak sejak dilaksanakannya. 


\section{b. Sumber Daya}

Berdasarkan pengamatan di lapangan serta wawancara yang dilakukan, terdapat beberapa sumber daya yang berperan pada kegiatan pelayanan HT-el dengan kewenangan masing-masing, yaitu:

1) Kementerian ATR/BPN melalui Pusdatin menyiapkan sistem yang akan digunakan untuk mengakses pelayanan HT-el, sebagai verifikator akun Kreditor yang berada di pusat melalui aplikasi mitra kerja, serta menyiapkan panduan pelaksanaannya yang kemudian disosialisasikan kepada Kantor Pertanahan.

2) Kantor Wilayah ATR/BPN, yang melakukan monitoring dan evaluasi kegiatan HT-el pada tiap2 Kantor Pertanahan.

3) Administrator aplikasi KKP untuk mengatur kalender pelayanan melalui aplikasi KKP dengan ketentuan yang berlaku.

4) Kepala Kantor Pertanahan selaku pejabat aktif berwenang bertanggung jawab atas hasil dan kuallitas data HT-el, melakukan monitoring, dan mengesahkan Sertipikat HT-el dengan menggunakan TTE atau melimpahkan kewenangan tersebut kepada pejabat yang ditunjuk.

5) Kepala Subseksi, Kepala Seksi atau pejabat fungsional yang menangani Hak Tanggungan untuk dilakukan pemeriksaan berkas.

6) Verfikator yang ditunjuk oleh Kepala Kantor sebagai pemeriksa pertama atas kelengkapan dokumen yang diupload, baik itu kesesuaian persyaratan dengan identitas, peringkat, dan lain sebagainya.

7) PPAT melakukan pendaftaran akun pada apalikasi mitra kerja, melakukan pembuatan akta, validasi dan bertanggung jawab penuh terhadap data yang diinput.

8) Kreditor melakukan pendaftaran akun pada aplikasi mitra kerja jasa keuangan. Kreditor Badan Hukum dapat berdiri sendiri atau mempunyai cabang sebagai kantor operasional yang melayani kredit. Kreditor Badan Hukum yang mempunyai cabang mendaftarkan akun admin pusat, akun admin kantor cabang, akun Supervisor/Penyelia dan akun operator. Kreditor Badan Hukum yang berdiri sendiri mendaftarkan akun admin pusat, akun Supervisor/Penyelia dan akun operator. Kreditor sebagai pemohon yang membuat berkas permohonan pada sistem HT-el dengan memasukkan Akta yang telah dibuat oleh PPAT.

Secara umum, pelaksanaan HT-el sudah berjalan dengan baik. Namun sumber daya manusia yang bertugas juga harus memadai, baik dari segi jumlah maupun kemampuan dalam menggunakan teknologi. Selain mengoperasikan dan mempelajari penggunaan akses pada sistem HT-el, untuk menjalankannya sumber daya manusia pada kantor PPAT dan Kreditor juga harus dapat mengubah dokumen dan berkas-berkas menjadi salinan dalam bentuk digital.

c. Disposisi/Kecenderungan

Dilihat dari sumber daya HT-el dengan kewenangan yang telah dijalankan dengan baik, maka para pihak telah paham akan tugas masing-masing dalam menjalankan HT-el sehingga dalam pelaksanaannya tidak mengalami kesulitan. Hal ini dikarenakan para sumber daya telah paham 
bahwa kebijakan yang dilaksanakan ini adalah kebijakan yang berkaitan dengan Visi dan Misi dari Kementerian ATR/BPN harus dilaksanakan dengan sungguh-sungguh dan penuh tanggung jawab. Tentu tidak mudah untuk mengubah suatu sistem pelayanan pertanahan hak tanggungan konvensional menjadi elektronik tersebut. Dibutuhkan suatu konsistensi dan kemauan dari sumber daya untuk mempelajari hal baru tersebut, agar dapat dijalankan dengan optimal untuk mencapai tujuannya. Dorongan dari penyelenggara dan pelaksana bagi pengguna, baik berupa edukasi, penyempurnaan sistem maupun bantuan akan permasalahan yang dialami jika pengguna layanan memiliki masalah, juga menjadi suatu kecenderungan untuk mencapai tujuannya. Apalagi pengguna layanan harus mendaftarkan, melengkapi dan mengubah dokumen cetak menjadi digital secara mandiri.

\section{d. Struktur Birokrasi}

Petunjuk teknis atau pelaksanaan merupakan salah satu unsur penting dari suatu implementasi yang baru akan diterapkan dan dilaksanakan. Peraturan Menteri ATR/Kepala BPN Nomor 5 tahun 2020 tentang Pelayanan Hak Tanggungan Terintegrasi secara Elektronik, yang menjadi dasar pedoman pelaksana yang dimuat pada Juknis 2/2020. Kementerian ATR/BPN sebagai penanggung jawab dari pelayanan HT-el telah melakukan koordinasi dengan baik kepada seluruh pelaksana, yaitu Kantor Pertanahan; dan pengguna layanan yaitu PPAT dan Kreditor, untuk bertanggung jawab atas kebijakan yang telah ditetapkan. Hal tersebut juga telah dilaksanakan dan dibuktikan dengan meningkatnya penggunaan HT-el dibandingkan dengan konvensional dan telah digunakan oleh seluruh Kantor Pertanahan di Indonesia.

Sejak dimulainya pelaksanaan pelayanan HT-el pada bulan September 2019, terdapat beberapa tujuan yang telah berhasil dicapai oleh Kantor Pertanahan Kota Batam, yaitu:

1. Meningkatkan kinerja dan kualitas pelayanan pertanahan Hak Tanggungan

Peningkatan pelayanan yang dimaksud adalah sistem yang telah terintegrasi secara elektronik dalam pelayanan Hak Tanggungan yang dapat otomatis terbit sertipikatnya setelah 7 hari bila telah sesuai dengan ketentuan yang mengatur. Dengan adanya pelayanan HT-el ini, tidak diperlukan lagi interaksi tatap muka, karena untuk berkas permohonan dapat dibuat langsung oleh pemohon yakni Kreditor. Selain itu, tidak dibutuhkan lagi ruang penyimpanan warkah karena dokumen telah tersimpan secara otomatis pada sistem saat PPAT dan Kreditor meng-upload persyaratan pada sistem ini.

2. Memenuhi asas keterbukaan dalam pelayanan Hak Tanggungan

Keterbukaan yang dimaksud adalah kemudahan dalam mengakses dan memperoleh informasi mengenai pelayanan HT-el. Seluruh pihak telah mendapatkan edukasi dan sosialisasi secara berjenjang dari penyelenggara hingga ke pengguna. Sistem HT-el ini juga dapat dimonitor secara langsung oleh penyelenggara, serta proses pengerjaan berkas juga dapat dilihat oleh pemohon. Besaran pembayaran biaya pelayanan juga telah diatur dalam perundang-undangan serta transparansi dalam pembayaran yang dilakukan oleh Kreditor setelah menerima SPS.

3. Memenuhi asas ketepatan waktu.

Penyelesaian HT-el dilakukan tepat waktu sesuai dengan standar pelayanan. Keterlambatan waktu dalam penyelesaian seharusnya tidak terjadi lagi, dimana peralihan 
dari HT konvensional menjadi elektronik sudah berjalan secara otomatis oleh sistem. Hal ini dibuktikan dengan tetap diterbitkannya Sertipikat HT pada hari ke-7 setelah konfirmasi pembayaran PNBP, meskipun Kantor Pertanahan belum melakukan pemeriksaan terhadap berkas tersebut. Rekapitulasi berkas tanpa periksa dapat dilihat dan diakses menggunakan akun KKP terdaftar.

4. Memenuhi asas kecepatan dan kemudahan

Kecepatan suatu layanan akan diperoleh jika pelaksananya memiliki sumber daya manusia yang kompetensi dengan jumlah yang memadai sesuai kebutuhan penyelenggara layanan. Kecepatan juga dirasakan dengan tanpa adanya tatap muka secara langsung, akan menghemat waktu perjalanan yang harusnya ditempuh untuk mendaftarkan permohonan pelayanan $\mathrm{HT}$.

Sedangkan kemudahan dimaksud adalah ketentuan persyaratan yang seharusnya dapat dengan mudah dipahami oleh berbagai pihak yang berkepentingan. Dari Juknis No.2/2020 telah dijelaskan secara rinci mengenai mekanisme dalam pelaksanaan HT-el yang memudahkan Kantor Pertanahan, PPAT dan Kreditor untuk memahaminya.

\section{F. Kendala yang Dihadapi dan Upaya Penyelesaian dalam Pelaksanaan HT-el}

Setiap kebijakan yang dijalankan oleh pemerintah tidak selamanya berjalan dengan baik, dikarenakan kebijakan akan suatu implementasi yang bersifat kompleks. Situasi ini mendorong timbulnya masalah-masalah yang rumit dalam implementasi suatu kebijakan (Winarno 2012, 214). Berdasarkan hasil observasi, wawancara secara langsung maupun secara virtual pada Kepala Kantor Pertanahan Kota Batam, Kepala Subseksi Pendaftaran Hak Tanah, Admin HT-el, PPAT dan Kreditor, ditemui beberapa hal yang menjadi kendala dan upaya yang dapat dilakukan dalam implementasi HT-el.

1. Gangguan terhadap Sistem HT-el

Dari persepsi PPAT dan Kreditor, masih terjadi gangguan pada sistem HT-el, seperti jaringan tidak dapat mengakses website HT-el, gagal dalam meng-upload file, data yang input dan hasil dokumen yang diupload tidak dapat dibaca oleh sistem dan lain sebagainya. Kreditor juga mengatakan bahwa hal ini mengakibatkan tertundanya penginputan data sehingga harus menunggu jaringan stabil untuk mengulang kembali proses tersebut untuk dapat dilanjutkan pada proses selanjutnya. Gangguan sistem ini disebabkan karena belum stabil sistem yang ada saat ini karena masih dalam masa peralihan peraturan. Perlu menjadi perhatian khusus bagi penyelenggara karena merupakan hal utama dalam melaksanakan HT-el. Menurut Kepala Subseksi Pendaftaran Hak Tanah, gangguan sistem yang terjadi merupakan suatu hal yang wajar, dimana suatu sistem yang masih dalam tahap perkembangan digunakan dan diakses oleh banyak pengguna secara bersamaan. Diperlukan uji coba terhadap kemampuan sistem baru dalam menjalankan proses pelayanannya. Sehingga akan menjadi suatu perbaikan untuk penyempurnaan sistem ke depannya.

Adapun untuk gangguan sistem, Kantor Pertanahan Kota Batam telah berupaya untuk menanggapi aduan dari Kreditor dan PPAT. Pada saat penelitian ini dilakukan, tidak ditemukan secara langsung kendala tersebut, namun ketika terjadi masalah terhadap sistem HT-el, Kreditor dan PPAT disarankan untuk melakukan refresh secara berkala menunggu sistem dapat digunakan 
kembali. Kemudian melaporkan perihal gangguan sistem tersebut kepada asosiasi pengembang, yaitu Pusdatin, untuk dilakukan pengecekan dan perbaikan sistem.

2. Belum mencakup debitor dengan penjamin yang berbeda

Sejak bulan September 2019, pelaksanaan HT-el diatur dalam Peraturan Menteri ATR/Kepala BPN Nomor 9 Tahun 2019. Pada Pasal 9 ayat 5 peraturan tersebut menyebutkan bahwa persyaratan berupa Sertipikat Hak Atas Tanah atau Hak Milik Atas Satuan Rumah Susun harus atas nama debitor. HT-el hanya dapat diproses untuk debitor yang penjaminnya sesuai dengan pemilikan hak tersebut, sehingga jika debitor pada pemohon Hak Tanggungan berbeda dengan pemilik hak belum dapat menggunakan sistem HT-el. Selain itu, menu pada sistem juga belum menyediakan kolom input nama debitor dengan lebih dari satu orang pemegang hak.

Berdasarkan wawancara kepada Kepala Kantor Pertanahan Kota Batam, saat ini untuk Debitor dengan penjamin yang berbeda masih menggunakan layanan pertanahan secara konvensional atau manual. Namun Peraturan Menteri ATR/Kepala BPN Nomor 9 Tahun 2019 diganti menjadi Peraturan Menteri ATR/Kepala BPN Nomor 5 Tahun 2020, dalam rangka penyelenggaraan pelayanan hak tanggungan terintegrasi secara elektronik menjadi salah satu upaya yang dilakukan oleh Kementerian ATR/BPN agar HT-el dapat dilaksanakan secara nasional. Sehingga, melalui peraturan tersebut, akan dilakukan penyempurnaan pada sistem HT-el yang akan memuat seluruh layanan Hak Tanggungan termasuk debitor dengan penjamin yang berbeda. Jangka waktu yang diberikan untuk pelaksanaan HT-el secara menyeluruh adalah 3 bulan setelah diterbitkannya peraturan tersebut.

\section{Kesalahan dalam data peringkat HT}

Berdasarkan wawancara kepada verifikator dan admin HT-el pada Kantor Pertanahan Kota Batam, kesalahan dalam peringkat pernah ditemukan. Hal ini terjadi jika pada catatan pendaftaran dokumen hak secara digital dengan fisik berbeda atau tidak sesuai dengan kondisi saat ini. Salah satunya adalah terdapat HT yang sudah di roya namun masih aktif dikarenakan HT pernah dilakukan aktivasi HT. Menurut Kepala Subseksi Pendaftaran Hak Tanah kesalahan ini memang terjadi akibat kelalaian dari petugas di Kantor Pertanahan yang kurang teliti atau lalai dalam pencatatan fisik menjadi digital, sehingga mengakibatkan terlewatnya pencatatan penghapusan Hak Tanggungan tersebut. Akibat dari itu, salahnya urutan peringkat yang keluar pada permohonan yang diproses oleh sistem HT-el tidak membaca catatan fisik yang harusnya melekat. Berdasarkan wawancara kepada admin HT-el di Kantor Pertanahan Kota Batam yang dilakukan oleh peneliti, diketahui bahwa Kantor Pertanahan Kota Batam telah melakukan validasi data secara tekstual dan spasial terhadap seluruh bidang tanah yang masih belum lengkap pada sistem di KKP. Namun ini tidak menutup kemungkinan akan terjadinya kesalahan dalam data peringkat. Sehingga cara yang dilakukan untuk menyelesaikan kendala ini adalah dengan membuka validasi data catatan pendaftaran dokumen hak yang terdaftar HT pada KKP, kemudian diperbaiki peringkat sesuai pada peringkat pada fisik buku tanah HT. Setelah diisi secara lengkap dan benar, lalu disimpan kembali dan klik validasi.

4. Berkas dibatalkan karena tidak sesuai dengan persyaratan

Pada Pasal 13 ayat (3) Peraturan Menteri ATR/BPN Nomor 5 Tahun 2020 menyebutkan apabila dalam pemeriksaan terdapat dokumen yang tidak lengkap atau tidak sesuai, maka akan 
diberitahukan kepada Kreditor dan/atau PPAT melalui email akun terdaftar untuk melengkapi dokumen tersebut. Selanjutnya, pada ayat (4) dijelaskan bahwa berkas akan tertutup dari sistem jika Kreditor dan/atau PPAT tidak melakukan perbaikan hingga hari ke-5 sejak permohonan diterima oleh Sistem HT-el. Berdasarkan data yang diperoleh pada saat observasi lapangan, terdapat 106 berkas permohonan yang ditutup karena berkas belum dilengkapi atau diperbaiki hingga melebihi batas waktu yang telah diatur sesuai peraturan yang berlaku. PNBP terhadap berkas yang ditutup akan dilakukan pengajuan pengembalian oleh Kantor Pertanahan. Selanjutnya, berkas yang sudah ditutup dapat didaftarkan kembali dengan permohonan berkas baru oleh Kreditor dan melakukan pembayaran SPS lagi.

Upaya awal yang dilakukan oleh Kantor Pertanahan Kota Batam dalam mengantisipasi berkas yang dibatalkan karena tidak sesuai adalah membuat komitmen terhadap PPAT dan Kreditor untuk memastikan bahwa berkas permohonan HT. Namun Kantor Pertanahan juga harus memastikan bahwa PPAT dan/atau Kreditor telah melalukan perbaikan sampai dengan upload dokumen untuk melanjutkan berkas hingga selesai. Komitmen dari PPAT dan Kreditor sangat dibutuhkan karena berkaitan dengan berkas permohonan pelayanan HT-el yang didaftarkan melalui Kantor Pertanahan. Jika berkas dibatalkan maka Kreditor harus melakukan pengulangan mulai dari awal, yaitu pembuatan berkas HT-el dan wajib melakukan pembayaran PNBP yang tertera pada SPS hingga diterima oleh sistem HT-el. Selain itu, proses pengembalian PNBP berkas yang dibatalkan tidak dapat dilakukan secara langsung, karena Kantor Pertanahan harus mengajukan pengembalian PNBP terlebih dahulu dan ini membutuhkan proses beberapa hari.

\section{G. Kesimpulan}

Berdasarkan hasil penelitian dan pembahasan yang telah dilakukan maka dapat ditarik kesimpulan bahw, pelaksanaan HT-el di Kantor Pertanahan Kota Batam telah sesuai dengan Peraturan Menteri ATR/Kepala BPN Nomor 9 Tahun 2019, dan dalam tahap persiapan untuk melaksanakan sesuai dengan peraturan pengganti yaitu Peraturan Menteri ATR/Kepala BPN Nomor 5 Tahun 2020. Debitor dengan penjamin berbeda belum sesuai dengan Peraturan Menteri ATR/Kepala BPN Nomor 5 Tahun 2020 tetapi masih dalam jangka waktu 3 bulan sejak diberlakukan. Adapun kendala yang dihadapi dalam proses pelayanan HT-el di Kantor Pertanahan Kota Batam adalah belum sempurnanya sistem dan aturan main yang belum sepenuhnya sesuai dengan kebutuhan proses penerbitan Hak Tanggungan.

\section{Rekomendasi}

Setelah menguraikan hasil penelitian pada pembahasan dan analisis terhadap pokok bahasan yang terkait dengan Implementasi Pelayanan Hak Tanggungan Terintegrasi Secara Elektronik di Kantor Pertanahan Kota Batam, peneliti memiliki beberapa saran yang dapat dijadikan sebagai bahan pertimbangan dan masukan untuk meningkatkan pelayanan HT-el di Kantor Pertanahan Kota Batam dan Kantor Pertanahan yang lain sebagai berikut:

a. Perlu dilakukan penelitian lanjutan terkait evaluasi implementasi HT-el terhadap Peraturan dan Petunjuk Teknis setelah masa 3 bulan ditetapkannya Peraturan Menteri ATR/Kepala BPN Nomor 5 Tahun 2020 yaitu sejak tanggal 8 Juli 2020, karena pada dasarnya penelitian ini lebih cenderung mengetahui implementasi 
pelayanan HT-el bukan mengetahui seberapa banyak kesesuaian kegiatan yang diatur pada Juknis 2/2020 yang dilaksanakan mengingat waktu terbitnya Juknis tersebut adalah pada tahap sosialisasi dan belum dapat dilaksanakan sepenuhnya.

b. Kementerian ATR/BPN melalui Kantor Pertanahan agar selalu memberikan sosialisasi yang berkaitan dengan sistem HT-el, karena sistem HT-el merupakan salah satu sistem yang dapat mempercepat dan meningkatkan pelayanan pertanahan dengan memberikan kemudahan bagi pengguna layanan untuk melayani masyarakat Indonesia pada umumnya dan di Kota Batam pada khususnya dalam melakukan proses Hak Tanggungan. Kantor Pertanahan juga dapat memberikan masukan serta pengaduan dari pengguna layanan melalui asosiasi pengembang kepada Menteri untuk tercapainya tujuan pelayanan Hak Tanggungan menggunakan Sistem HTel secara optimal.

c. Penerbitan sebuah peraturan dan petunjuk teknis harus diikuti dengan sistem yang telah mendukung pelaksanaan yang diatur di dalamnya, seperti nama debitor sebagai penjamin yang berbeda dengan nama pemilik sertipikat, dan debitor yang pemiliknya lebih dari satu orang.

d. Meminimalisir kesalahan peringkat HT diperlukan penambahan pilihan peringkat pada sistem HT-el pada saat pendaftaran berkas oleh Kreditor. Selain itu, diperlukan ketelitian bagi pengguna layanan dan pelaksana untuk melakukan pengecekan peringkat Hak Tanggungan yang dimohonkan sebelum berkas dikonfirmasi untuk diterbitkan sertipikat Hak Tanggungan, agar tidak terjadi kesalahan yang dapat menimbulkan permasalahan dikemudian hari.

e. Memperketat keamanan akun dengan pembaharuan sistem keluar secara otomatis (auto log out) apabila tidak dioperasikan selama beberapa waktu. Dengan adanya sistem auto log out ini, menurut pengguna layanan dapat mengurangi tindakan penyalahgunaan akun.

f. Menambahkan tampilan aplikasi dengan menu jendela baru/new tab pada Sistem HT-el pada saat dilakukannya pengecekan berkas dan dokumen. Hal ini ditujukan agar berkas dapat disandingkan bersebelahan untuk memudahkan serta meminimalisir kesalahan yang dapat terjadi dalam pemeriksaan berkas oleh petugas

\section{Daftar Pustaka}

Buku

Creswell, J. W. (2014). Research Design: Qualitative, Quantitative and Mixed Methods.

Hardiyansyah, H. (2018). Kualitas Pelayanan Publik: Konsep, dimensi, Indikator dan Implementasinya. Gava Media.

Mardalis. (2014). Metode Penelitian Suatu Pendekatan Proposal. Bumi Aksara.

Moleong, L. J. (2012). Metode Penelitian Kualitatif. Remaja Rosdakarya.

Sinambela, L. P. (2011). Reformasi pelayanan publik: Teori, kebijakan, dan implementasi (6th ed.). Bumi Aksara.

Tangkilisan, H. N. S. (2005). Implementasi kebijakan publik: transformasi pikiran George Edwards. Lukman offset.

Winarno, B. (2014). Kebijakan publik, teori, proses, dan studi kasus (cetakan kedua). Yogyakarta: Center of Academic Publishing Service, CAPS. 


\section{Jurnal}

Mustofa, F. C., \& Aditya, T. (2009). Aplikasi Layanan Informasi Pertanahan Berbasis Web Services (Web Services Based Application Of Land Information Service). BHUMI: Jurnal Agraria Dan Pertanahan, $1(1)$. https://www.researchgate.net/publication/326080169_Aplikasi_Layanan_Informasi_Pertan ahan_Berbasis_Web_Services_Web_Services_Based_Application_Of_Land_Information_Ser vice

Nadira, N. (2019). Pendaftaran Hak Tanggungan Elektronik Yang Akan Mulai Dilaksanakan Di Badan Pertanahan. Fairness and Justice: Jurnal Ilmiah Ilmu Hukum, 17(2), 162-165. https://doi.org/10.32528/FAJ.V17I2.2801

Nurwulan, P. (2021). Implementasi Pelayanan Hak Tanggungan Elektronik Bagi Kreditor dan Pejabat Pembuat Akta Tanah. Jurnal Hukum lus Quia Iustum, 28(1), 183-202. https://doi.org/10.20885/iustum.vol28.iss1.art9

Prafitasari, A. (2016). Organisasi Kepemudaan yang Efektif dalam Meningkatkan Partisipasi Masyarakat Desa Darungan Kecamatan Wlingi. 4, 31-48.

Setiawan, C., \& Emirsa, E. S. (2014). Analisis Kebijakan Terkait Prioritas Pilot Project Implementasi Sistem Informasi Menggunakan Analytical Hierarchy Process. Jurnal Pekommas, 17(3), 129138. https://doi.org/10.30818/JPKM.2014.1170301

Wicaksono, A. (2015). Harmonisasi Hukum Pengelolaan Sumber Daya Alam di Indonesia. Jurnal Bhumi, 1(2), 123-134. https://garuda.ristekbrin.go.id/documents/detail/907739 